\title{
Air Leakage Rates in Typical Air Barrier Assemblies
}

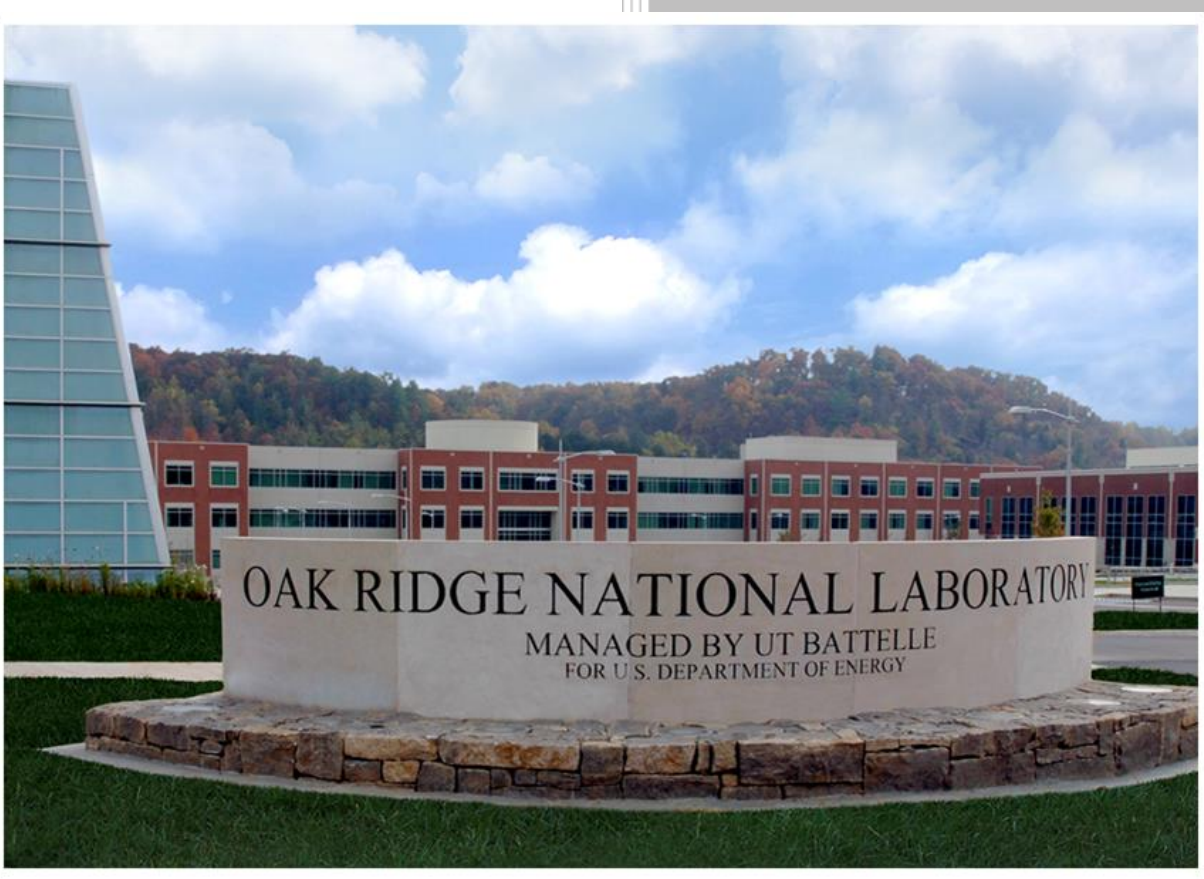

Approved for public release Distribution is unlimited

Diana E. Hun Jerry Atchley

Phil Childs

November 2016 


\title{
DOCUMENT AVAILABILITY
}

Reports produced after January 1, 1996, are generally available free via US Department of Energy (DOE) SciTech Connect.

Website http://www.osti.gov/scitech/

Reports produced before January 1, 1996, may be purchased by members of the public from the following source:

\author{
National Technical Information Service \\ 5285 Port Royal Road \\ Springfield, VA 22161 \\ Telephone 703-605-6000 (1-800-553-6847) \\ TDD 703-487-4639 \\ Fax 703-605-6900 \\ E-mail info@ntis.gov \\ Website http://www.ntis.gov/help/ordermethods.aspx
}

Reports are available to DOE employees, DOE contractors, Energy Technology Data Exchange representatives, and International Nuclear Information System representatives from the following source:

Office of Scientific and Technical Information

PO Box 62

Oak Ridge, TN 37831

Telephone 865-576-8401

Fax 865-576-5728

E-mail reports@osti.gov

Website http://www.osti.gov/contact.html

This report was prepared as an account of work sponsored by an agency of the United States Government. Neither the United States Government nor any agency thereof, nor any of their employees, makes any warranty, express or implied, or assumes any legal liability or responsibility for the accuracy, completeness, or usefulness of any information, apparatus, product, or process disclosed, or represents that its use would not infringe privately owned rights. Reference herein to any specific commercial product, process, or service by trade name, trademark, manufacturer, or otherwise, does not necessarily constitute or imply its endorsement, recommendation, or favoring by the United States Government or any agency thereof. The views and opinions of authors expressed herein do not necessarily state or reflect those of the United States Government or any agency thereof. 
Building Technologies Research and Integration Center

\section{Air Leakage Rates in Typical Air Barrier Assemblies}

Diana E. Hun

Jerry Atchley

Phil Childs

November 2016

Prepared by

OAK RIDGE NATIONAL LABORATORY

Oak Ridge, TN 37831-6283

managed by

UT-BATTELLE, LLC

for the

US DEPARTMENT OF ENERGY

under contract DE-AC05-00OR22725 



\section{CONTENTS}

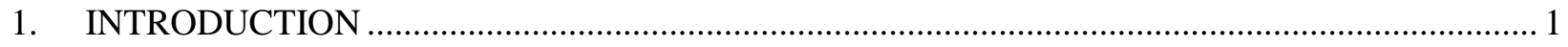

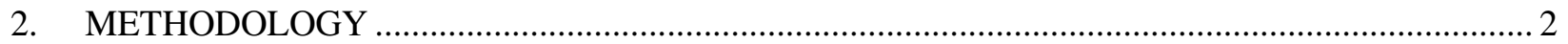

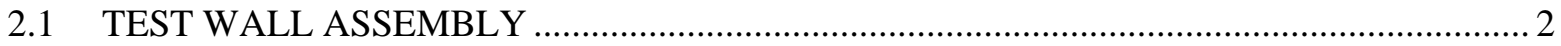

2.2 AIRFLOW PATHS ........................................................................................ 5

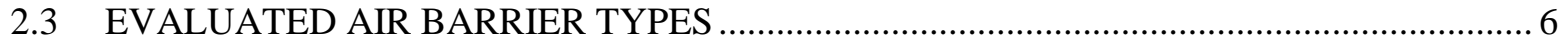

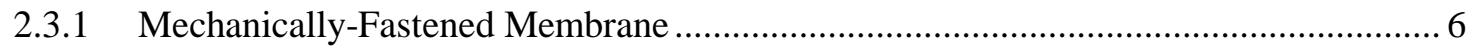

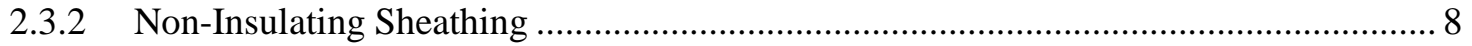

2.3.3 Insulating Sheathing.............................................................................. 9

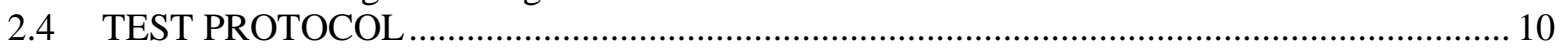

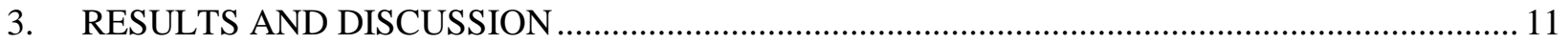

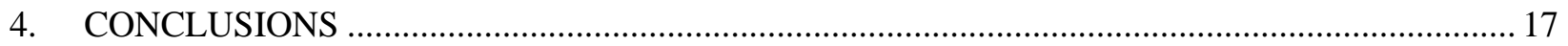

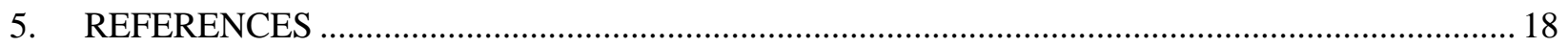




\section{ACKNOWLEDGEMENTS}

This work was supported by the Assistant Secretary for Energy Efficiency and Renewable Energy, Office of the Building Technology Program, U.S. Department of Energy, under Contract No. DE- AC0500OR22725. 


\section{INTRODUCTION}

Estimates for 2010 indicate that infiltration in residential buildings was responsible for 2.85 quads of energy (DOE 2014), which is about 3\% of the total energy consumed in the US. One of the mechanisms being implemented to reduce this energy penalty is the use of air barriers as part of the building envelope. These technologies decrease airflow through major leakage sites such as oriented strand board (OSB) joints, and gaps around penetrations (e.g., windows, doors, pipes, electrical outlets) as indicated by Hun et al. (2014). However, most air barrier materials do not properly address leakage spots such as wall-to-roof joints and wall-to-foundation joints because these are difficult to seal, and because air barrier manufacturers usually do not provide adequate instructions for these locations.

The present study focuses on characterizing typical air leakage sites in wall assemblies with air barrier materials. This information is needed because it will show builders that if these imperfections are left unsealed, they will be among the dominant sources of airflow in tightly-built homes. Furthermore, researchers require air leakage measurements from these typical sites to improve their evaluations on the hygrothermal performance of energy-efficient walls given that most researchers assume airflow values in their models (Lepage et al. 2013). Maref and Saber (2015) provide airflows from laboratory experiments, but the usefulness of these data is somewhat limited by the fact that the measurements are from air barrier assemblies that do not include all the wall materials that affect flow (e.g., drywall), and because the measurements were derived from entire air barrier assemblies and not from specific leakage areas. Therefore, the objective of this study was to conduct laboratory tests to:

1. Measure the airflow rates through typical air leakage sites in tightly-built homes;

2. Raise awareness among builders about areas where the continuity of the air barrier is often compromised;

3. Provide designers and researchers with airflow rates that they can use in their simulations;

4. Evaluate the performance of three air barrier types that are or may soon be commonly installed in the US; and

5. Provide contractors with potential recommendations on how to seal typical leakage sites in walls with air barriers.

The following three air barrier types were chosen for evaluation because these were recommended by an advisory panel of building science experts, and because of their deployment potential in new construction:

1. Mechanically-fastened membrane: we selected to assess these membranes or housewraps because about $74 \%$ of new homes that were built in 2011 used them as a water barrier (HIRL 2013), although information was not provided on how common it was for these membranes to have been installed as the air barrier. The adoption of mechanically-fastened membranes as air barriers will be highly dependent on adequate training and the availability of wraps that comply with the requirements per ASTM E2357.

2. Non-insulating sheathing: we used OSB with an integrated overlay as the non-insulating sheathing because their share of the market has been increasing due to their multi-purpose capabilities: resists wind loads and serves as the air and water barrier. Furthermore, the installation of this type of OSB follows the typical procedure that is used by framers; the only difference is that OSB joints need to be taped to ensure continuity of the air barrier. 
3. Insulating sheathing: we decided to evaluate insulating sheathings as part of this study because of their introduction into building codes, such as the 2012 International Energy Conservation Code (IECC), as exterior continuous insulation. We used 1"-thick extruded polystyrene (XPS) boards as the insulating sheathing because it has a thermal resistance of R5, which is the minimum required by the 2012 IECC in $2 \times 4$ stud walls that are located in climate zones 3 thru 5 , and in $2 \times 6$ stud walls that are situated in climate zones 6 thru 8. In order to resist the pressures that are prescribed in ASTM E2357, we installed OSB between the XPS and the studs.

\section{METHODOLOGY}

\subsection{TEST WALL ASSEMBLY}

The airtightness level of walls is highly dependent on the workmanship skills of the installers as well as the condition of the construction materials (e.g., uneven surfaces and rough finishes). To capture the effect of these variables, nine test walls were built for each air barrier type and three technicians took turns assembling the test walls to introduce differences in skills. In order to conduct these experiments in a cost-effective manner, the test frame was divided to accommodate three 2'-0" wide by 8'-0" tall walls as shown in Figure 1. The perimeter of each of these walls was sealed so that air would not flow between walls. Figure 2 illustrates the assembly of the materials as they would be found in actual construction, and how the wall-to-roof and wall-to-foundation joints were incorporated into the test walls. Per Figures 2 and 3, the materials used typically included: $1 / 2$ " drywall, $2 \times 6$ studs at 24 " on center, R 21 unfaced fiberglass batts between studs, 7/16" OSB, air and water barrier, and vinyl siding. The insulation level was selected based on the fact that it is the minimum amount required per the 2012 IECC in walls without continuous exterior insulation in climate zones 3 and above. Indoor electrical outlets had a regular cover plate, outdoor outlets had typical weatherproof covers, and all of the outlets included the receptacle and wiring. Figure 3 also shows that each test wall had an airtight removable cover; these were used to mask the three test walls when measuring the extraneous leakage of the setup, and to mask two of the compartments so airflow rates through the wall of interest could be measured. 


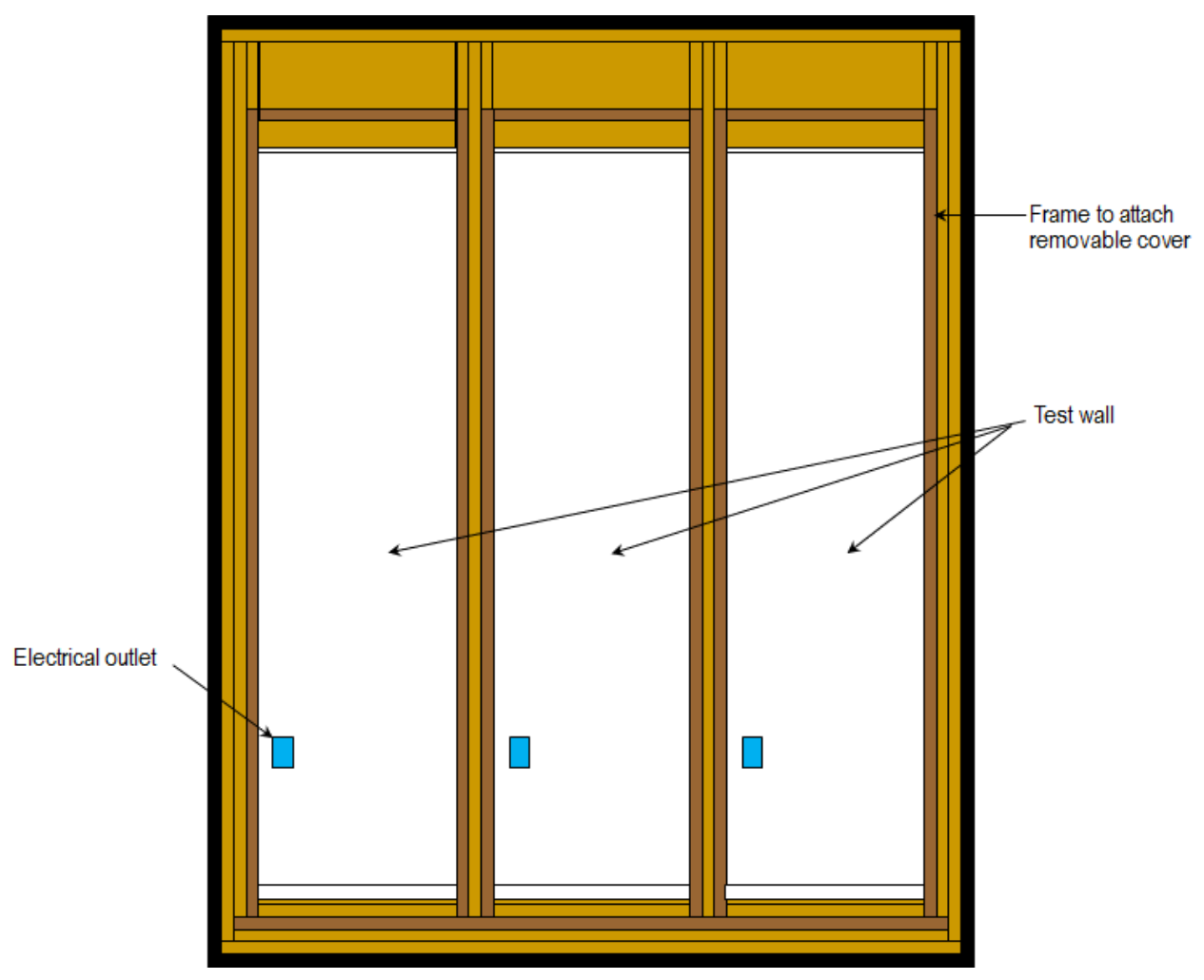

Figure 1. Indoor view of test frame with three test walls. 

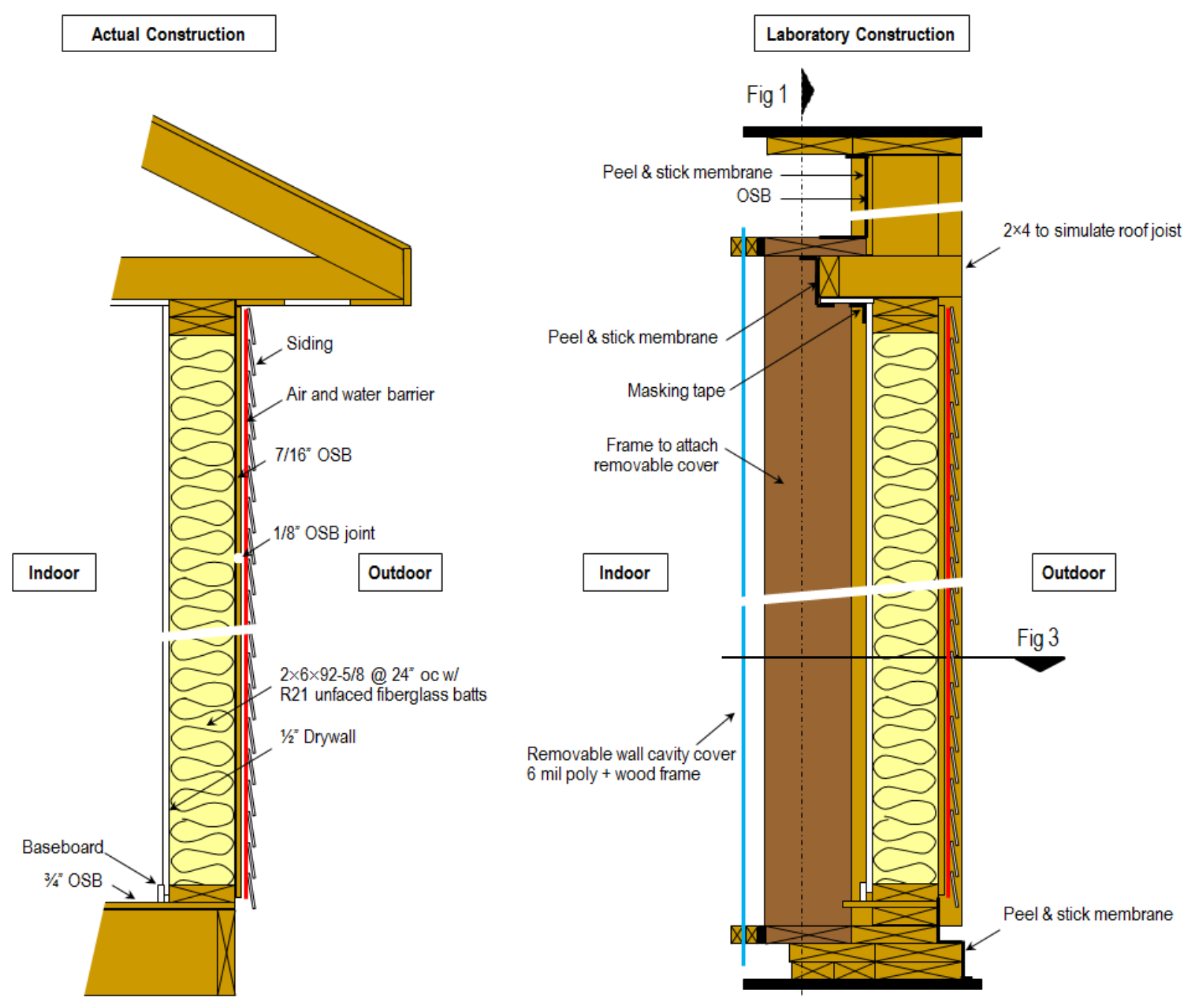

Figure 2. Wall material layout in actual construction and test walls.

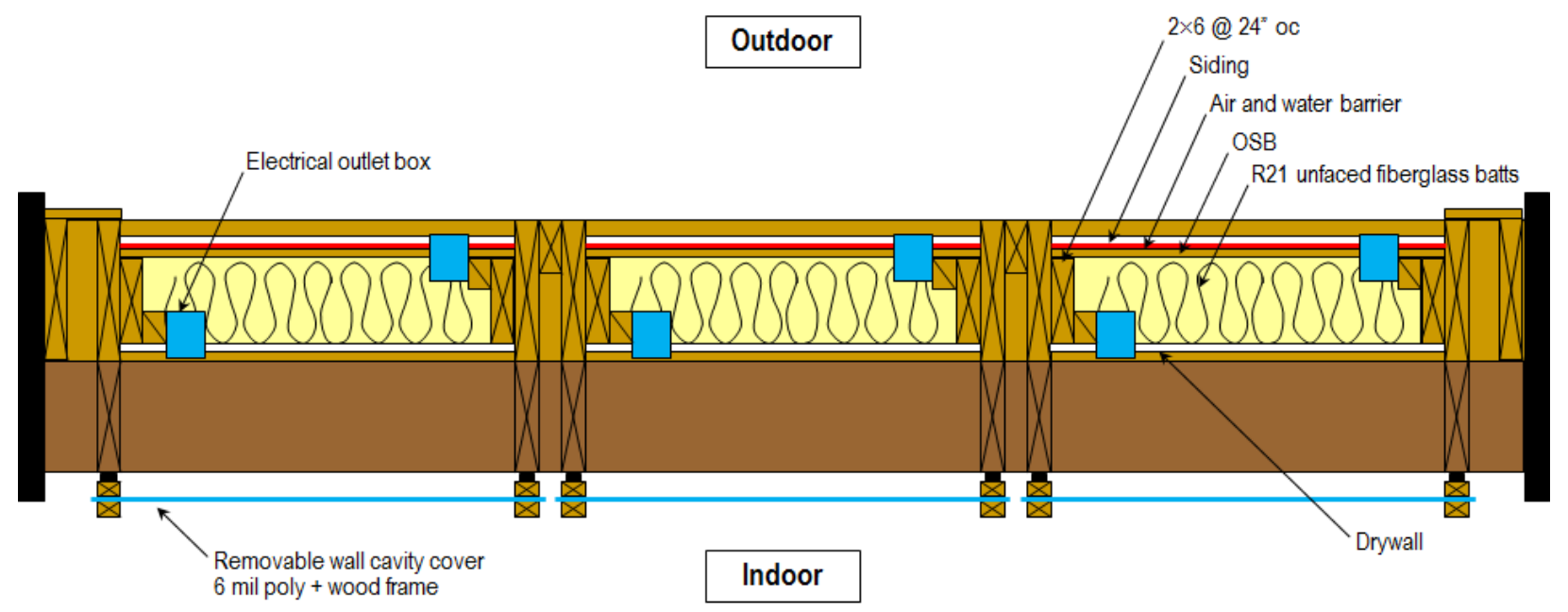

Figure 3. Horizontal cross sectional view of test frame with three test walls. 


\subsection{AIRFLOW PATHS}

Figure 4 shows the evaluated infiltration paths; these were selected because they are frequently encountered given that air barrier manufacturers usually do not provide clear instructions on how they should be sealed. In these scenarios, airflows were measured from the following entry point locations: wall-to-roof joint, wall-to-ceiling joint, wall-to-foundation joint, and outdoor electrical outlet with weatherproof cover. The inflow area of interest was isolated by sealing the other potential leakage spots with tape. In each of these instances, outflow could have only occurred through the indoor electrical outlet with cover plate or at the wall-to-floor joint because the side edges of the drywall were taped to the test frame and the drywall joints were covered with a fiberglass mesh and compound. Exfiltration rates were also collected from the same four leakage spots as indicated in Figure 5.

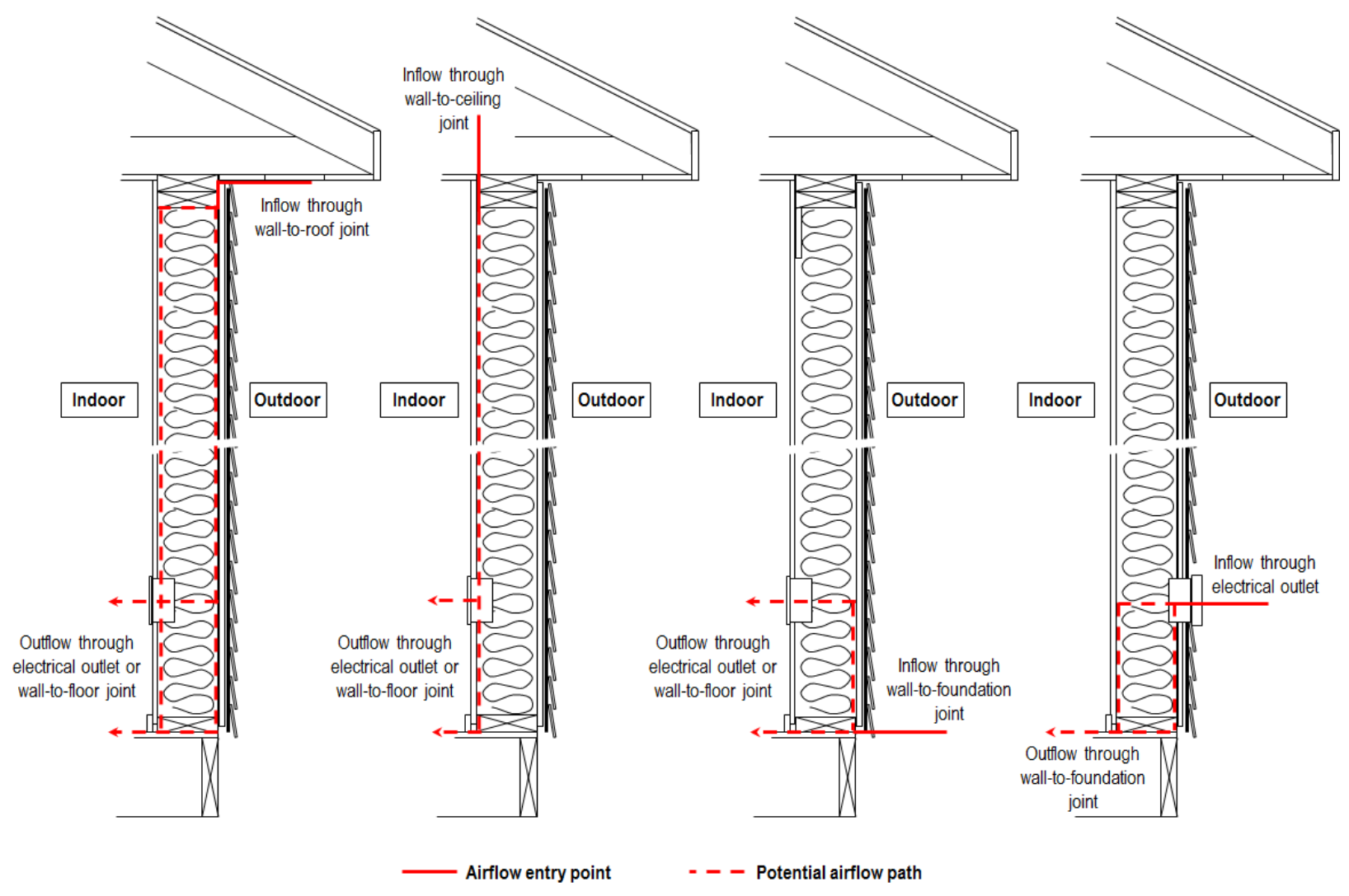

Figure 4. Locations where infiltration rates were assessed. 


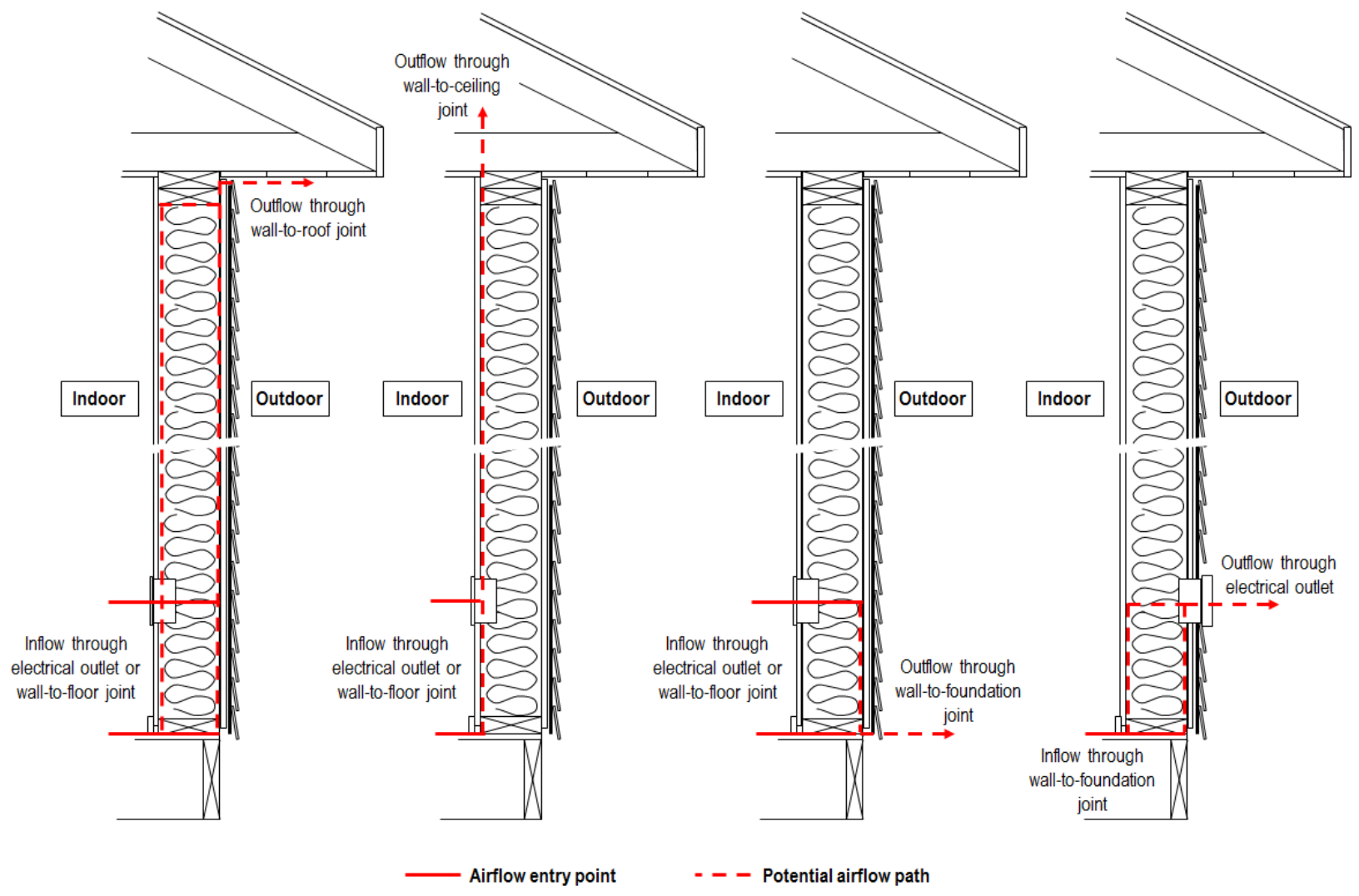

Figure 5. Locations where exfiltration rates were assessed.

\subsection{EVALUATED AIR BARRIER TYPES}

\subsubsection{Mechanically-Fastened Membrane}

Figure 6 illustrates the layout of materials in the test walls and how the mechanically-fastened membrane was installed as the air barrier. Screws were utilized instead of nails to attach the OSB to the studs to help preserve the wood framing of the three wall compartments as these frames were used in all of the tests in this project. The vertical sides of the housewrap were taped to the test frame to simulate horizontal continuity. Per the manufacturer's specifications, the fasteners consisted of staples with 1" diameter plastic caps, and horizontal membrane joints were taped. Moreover, the membrane extended 2" above the top plate and 2" below the bottom plate so it could be sealed to the roof and foundation, respectively, in order to maintain air barrier continuity per the manufacturer's instructions. Figures 7 and 8 show pictures of the actual test wall. 

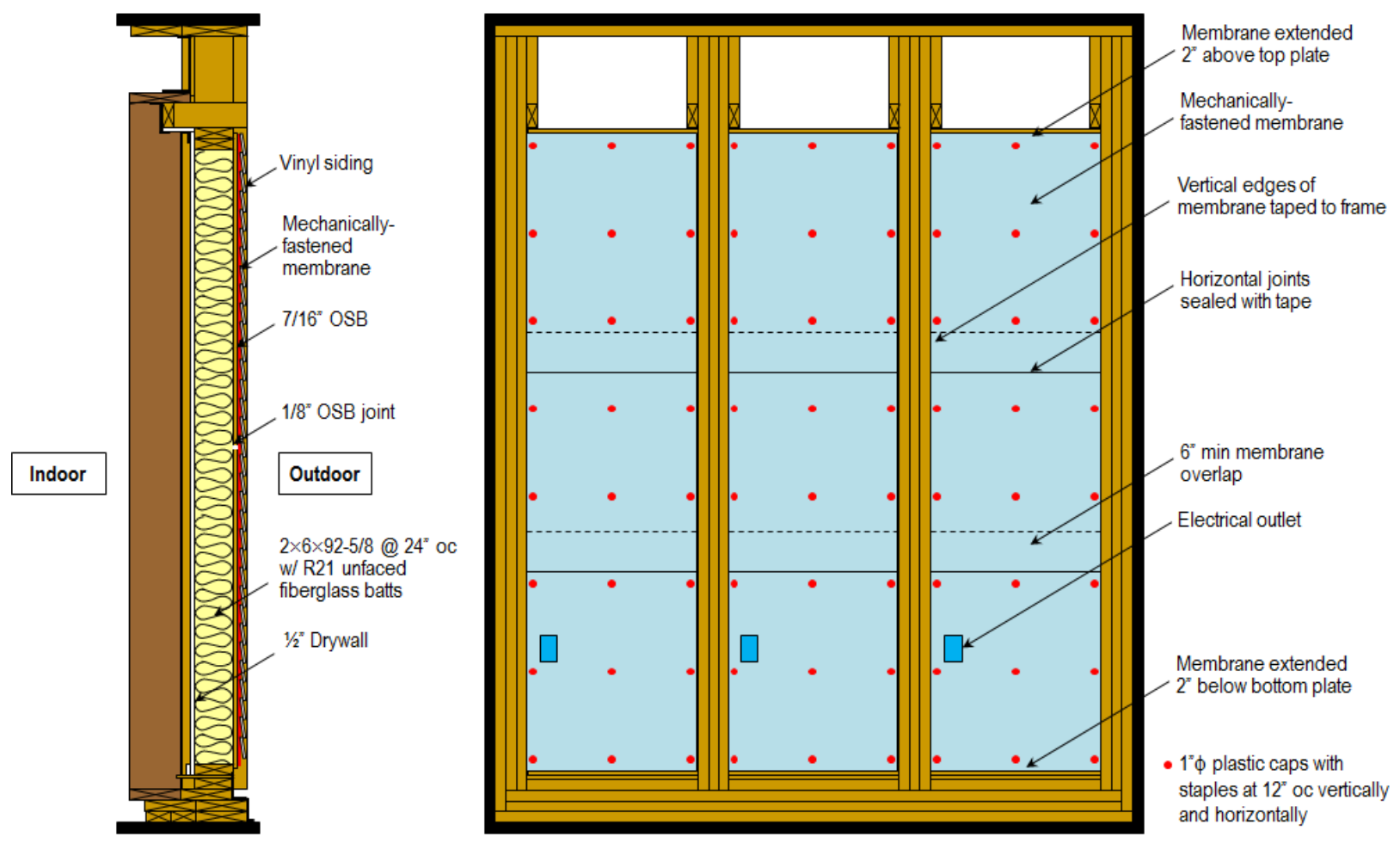

Figure 6. Material layout in test walls with mechanically-fastened membrane as the air barrier.
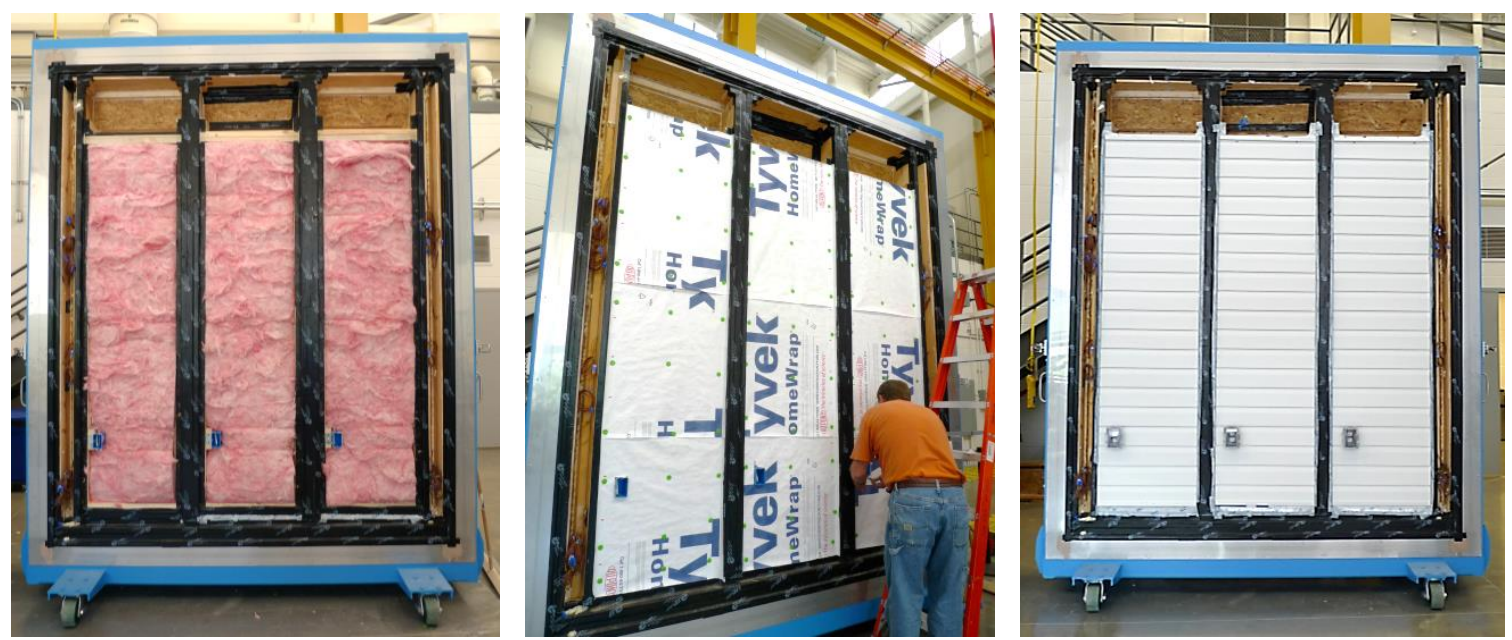

Figure 7. Test walls with mechanically-fastened membrane as the air barrier. 

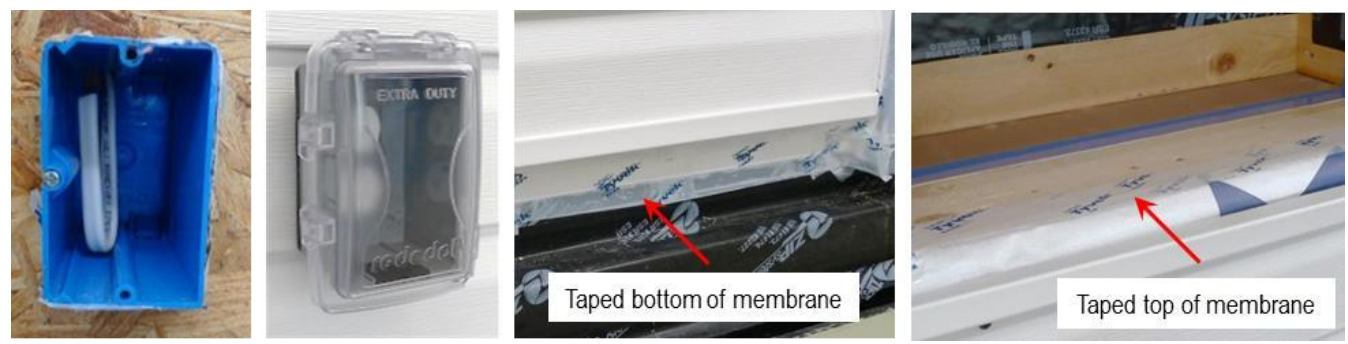

Figure 8. Construction details from test walls with mechanically-fastened membrane.

\subsubsection{Non-Insulating Sheathing}

Figure 9 describes the material layout in the test walls where OSB with an integrated overlay served as the non-insulating sheathing air barrier. Screws were utilized instead of nails to attach the OSB to the studs. The vertical sides of the OSB were taped to the test frame to simulate horizontal continuity. Vinyl siding was not installed because it would not affect the airtightness of the wall assembly given that OSB is a rigid material; however, the fasteners for the siding were installed as these could have a detrimental effect. Figure 9 shows pictures of the finished walls.
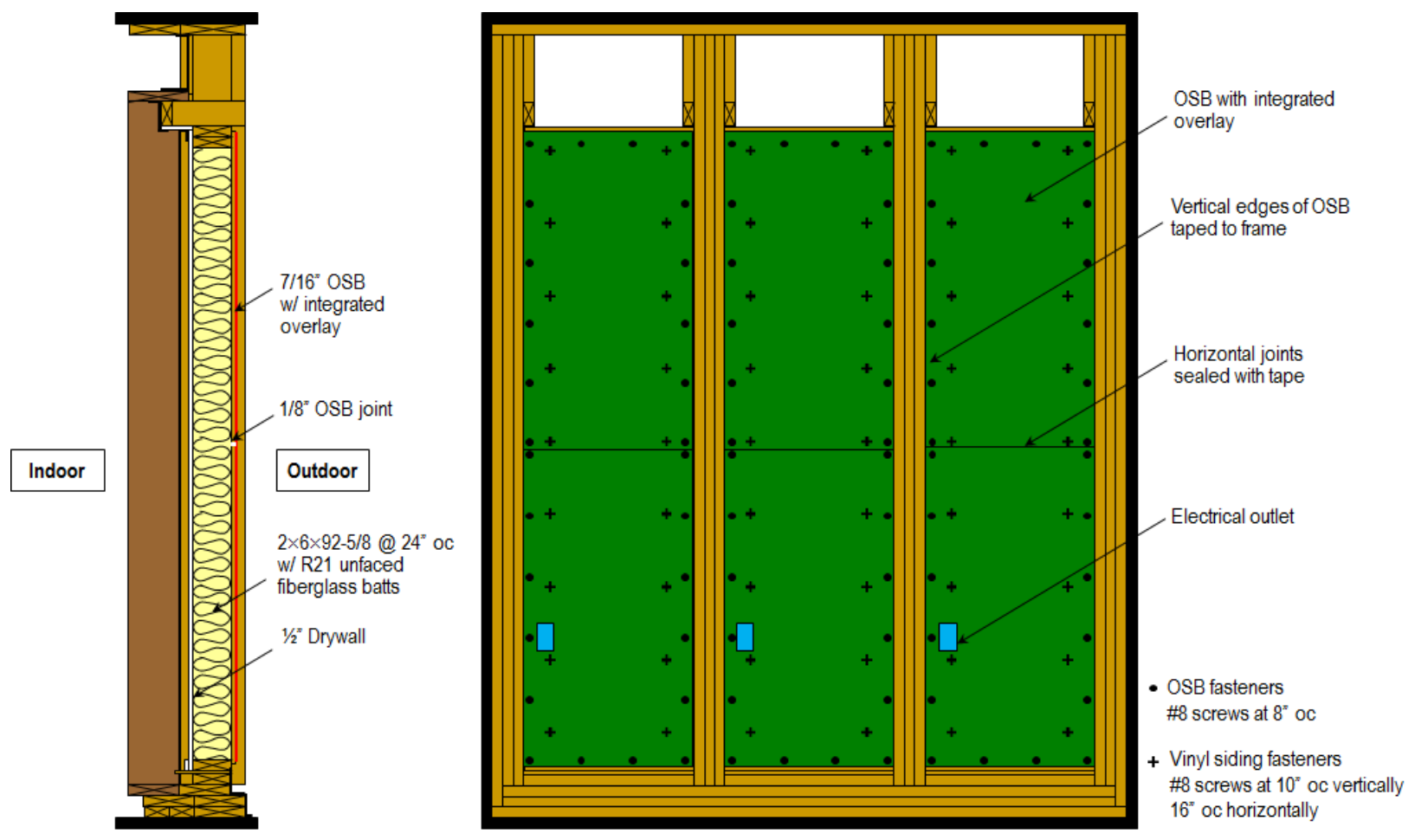

Figure 9. Material layout in test walls with non-insulating sheathing as the air barrier. 

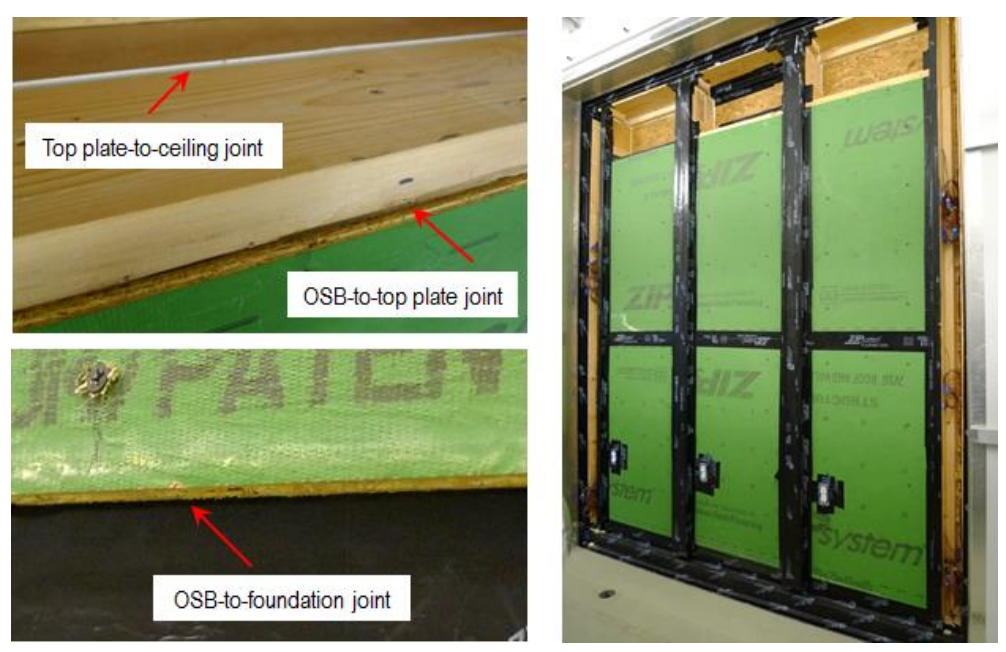

Figure 10. Construction details from test walls with non-insulating sheathing.

\subsubsection{Insulating Sheathing}

The wall material layout is depicted in Figure 11. The 1"-XPS boards were installed with their long side perpendicular to the ground because this is how they would likely be placed in actual construction.

Although the XPS boards did not include a horizontal joint, the OSB behind them did have an untapped horizontal joint at mid height. The insulation boards were attached to the studs using 2-1/2" nails with 1" diameter plastic caps per the manufacturer's instructions, while \#8 screws at 8 " on center were used with the OSB. The vertical sides of the OSB and XPS were taped to the test frame to simulate horizontal continuity. Only the fasteners for the vinyl siding were installed because it is unlikely that the cladding will affect the air leakage measurements given the rigidity of the OSB and XPS. 

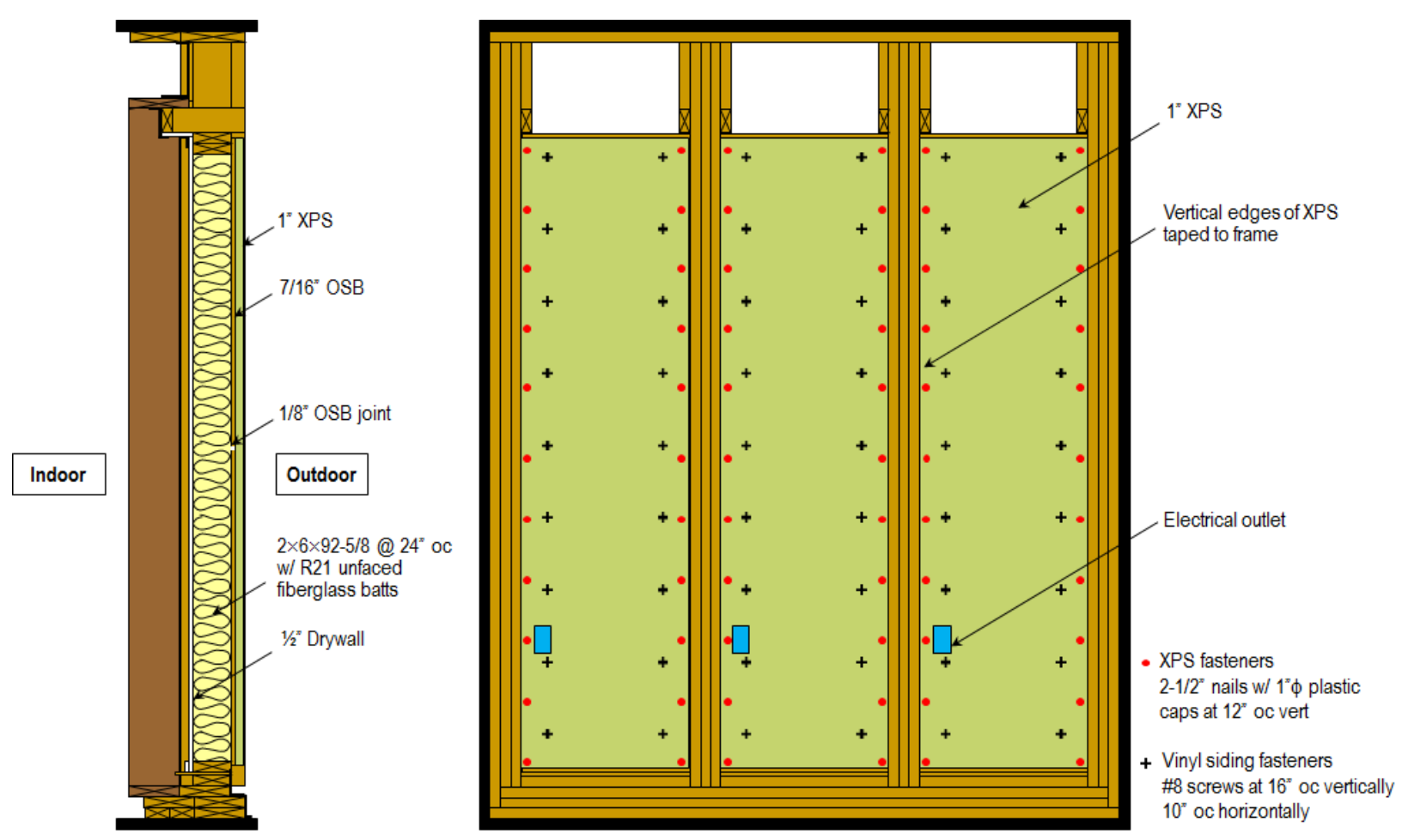

Figure 11. Material layout in test walls with insulating sheathing as the air barrier.
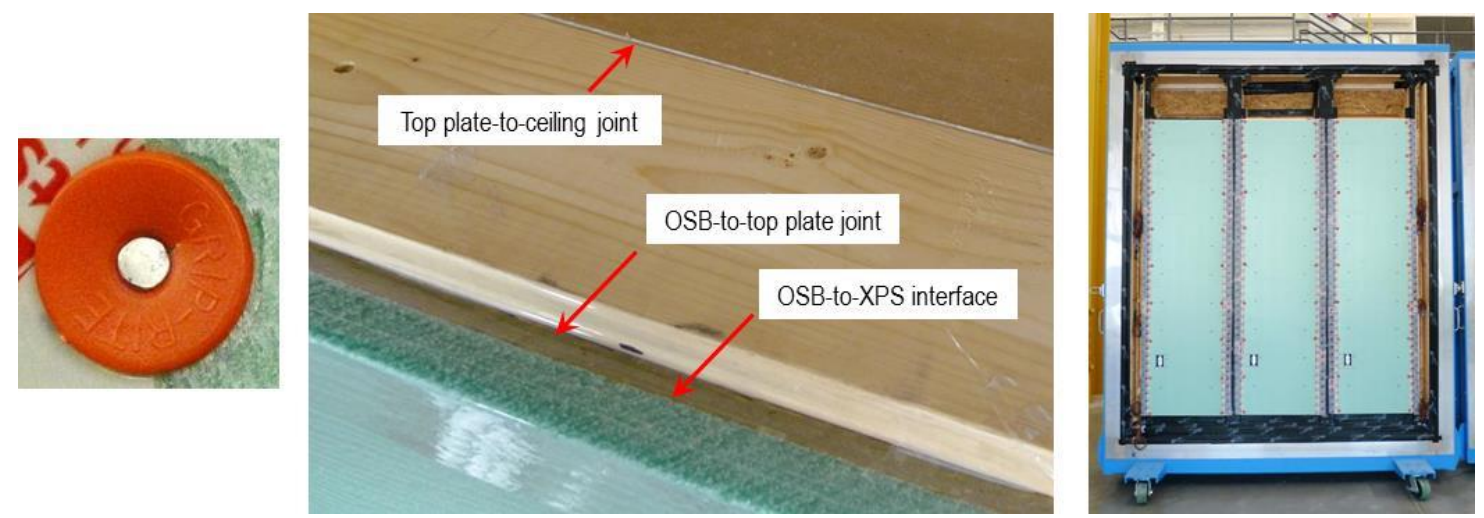

Figure 12. Construction details from test walls with insulating sheathing.

\subsection{TEST PROTOCOL}

Tests were performed with ORNL's heat, air and moisture penetration chamber, which allows a test wall to be simultaneously exposed to controlled indoor and outdoor conditions (e.g., temperature, relative humidity and pressure). Airflow rates through the test walls were measured with an EPI 8732MPNHSSS-133-DC24-Air meter. The minimum and maximum flow rates that can be measured with this device are $1.46 \mathrm{cfm}$ and $30.5 \mathrm{cfm}$, respectively, after following the in-situ calibration procedure described in ASTM E283. The accuracy of the meter is $+/-5 \%$ of the reading per the manufacturer's certificate. 
Air leakage rates were obtained by following ASTM E283, although lower pressure differentials were used because the removable covers shown in Figure 3 were unlikely to sustain the pressures prescribed in this standard. Instead, airflows were collected at the positive and negative pressure differentials of 20, 30, 40, 50, 60, 70 and $80 \mathrm{~Pa}$. Leakage rates were normalized to the standard temperature and pressure conditions of $14.7 \mathrm{psi}(101.3 \mathrm{kPa})$ and $69.4^{\circ} \mathrm{F}\left(20.8^{\circ} \mathrm{C}\right)$, respectively. Measurements were used to derive the airflow equation that was used to calculate the reported flow rates at $50 \mathrm{~Pa}$.

The steps that were followed to collect the infiltration and exfiltration rates were:

1. Blank the three test walls with the removable covers and measure the extraneous leakage rate of the test $\operatorname{setup}\left(Q_{\text {ext setup }}\right)$.

2. Remove the cover from the test wall of interest, seal the four leakage locations shown in Figure 4, and measure the wall's extraneous leakage rate $\left(Q_{\text {ext wall } m}\right)$.

3. Measure the leakage rate through the four locations shown in Figure 4:
a. Wall-to-roof joint $\left(Q_{w r m}\right)$
where $\quad Q_{w r}=Q_{w r m}-Q_{\text {ext wall } m}$
b. Wall-to-ceiling joint $\left(Q_{w c m}\right)$
where $\quad Q_{w c}=Q_{w c m}-Q_{\text {ext wall } m} \quad$ [2]
c. Wall-to-foundation joint $\left(Q_{w f m}\right)$
where $\quad Q_{w f}=Q_{w f m}-Q_{\text {ext wall } m} \quad$ [3]
d. Electrical outlet with weatherproof cover $\left(Q_{e o m}\right)$
where $\quad Q_{e o}=Q_{e o m}-Q_{\text {ext wall } m} \quad$ [4]

To gather these measurements, leave the leakage site of interest unobstructed and seal the other three with tape.

4. Measure the combined leakage rate from the four previously listed sites $\left(Q_{\text {unsealed }}\right)$,

where $Q_{\text {unsealed }}=Q_{\text {unsealed } m}-Q_{\text {ext setup. }} \quad$ [5]

Note that $Q_{\text {unsealed }}$ is not equivalent to the sum of the four leakage rates measured in step 3 because these include the resistance of various materials in the wall assembly, among which the drywall is likely to dominate.

5. Repeat steps 1 to 4 with another test wall.

6. After the three test walls have gone through steps 1 to 4, dismantle and replace the drywall, fiberglass batts, OSB, air barrier and siding.

7. Repeat steps 1 to 6 three times to obtain leakage measurements from nine test walls.

\section{RESULTS AND DISCUSSION}

Tables 1, 2 and 3 summarize the gathered flow rates from $2^{\prime} \times 8^{\prime}$ walls at a pressure differential $(\Delta P)$ of 50 $\mathrm{Pa}$. The collected measurements illustrate the variability due to workmanship given that flow rates vary up to $200 \%$ from their average values. This variability will likely be higher under actual outdoor conditions than laboratory conditions. In general, leakages through the electrical outlets $\left(\sim 0.08 \mathrm{cfm} 50 / \mathrm{ft}^{2}\right)$ were greater than at the wall-to-roof $\left(\sim 0.05 \mathrm{cfm} 50 / \mathrm{ft}^{2}\right)$ and wall-to-foundation $\left(\sim 0.05 \mathrm{cfm} 50 / \mathrm{ft}^{2}\right)$ joints when mechanically-fastened membranes and OSB were used as the air barrier. In the wall with XPS as the air barrier, airflows through the joints $\left(\sim 0.1 \mathrm{cfm} 50 / \mathrm{ft}^{2}\right)$ were greater than those through the outlets 
perhaps because the interface between the OSB and the XPS provided for an extra leakage site (Figure 12).

The 2012 IECC specifies the maximum leakage rate at a $\Delta P$ of $75 \mathrm{~Pa}$ to be $0.04 \mathrm{cfm} 75 / \mathrm{ft}^{2}$ for air barrier assemblies that are tested under laboratory conditions per ASTM E283 and ASTM E2357. We used the following flow rate equation to convert this value to a flow rate at a $\Delta P$ of $50 \mathrm{~Pa}$.

$Q=C \Delta P^{n}$

where $Q$ is the airflow rate in $\mathrm{cfm}, C$ is the leakage coefficient and it is a constant for a particular airflow path, $\Delta P$ is the pressure differential across the test wall in Pa, and $n$ is the flow exponent. We estimated $C$ by knowing $\Delta P$ to be $75 \mathrm{~Pa}$ and assuming the exponent to be 0.65 ; with these values we calculated that the maximum allowed leakage at a $\Delta P$ of $50 \mathrm{~Pa}$ to be $0.03 \mathrm{cfm} 50 / \mathrm{ft}^{2}$. According to Tables 1,2 and 3 , most of the average leakage rates were greater than $0.03 \mathrm{cfm} 50 / \mathrm{ft}^{2}$; consequently, they do not meet the code requirement.

To place the data in Tables 1, 2 and 3 into context, we estimated their contribution to the total air changes per hour at a $\Delta P$ of $50 \mathrm{~Pa}(\mathrm{ACH} 50)$. To achieve this, we use as an example a single-story house with a $2,000 \mathrm{ft}^{2}$ footprint, $8 \mathrm{ft}$ ceiling, 16,000 $\mathrm{ft}^{3}$ volume, and exterior wall area of 1,431 $\mathrm{ft}^{2}$. The $2012 \mathrm{IECC}$ leakage requirement for homes in climate zones 3 and above is $3 \mathrm{ACH} 50$, which in the proposed scenario is equivalent to $800 \mathrm{cfm} 50$. If we use $0.15 \mathrm{cfm} / \mathrm{ft}^{2}$ as the average leakage rate for all of the test walls when all the imperfections are left unsealed $\left(Q_{\text {unsealed }}\right.$ in Tables 1,2 and 3$)$ and multiply it times the exterior wall area, we find the flow rate through these walls to be $215 \mathrm{cfm} 50$. That is, the leakage rate through the imperfections that were evaluated in this study would be equivalent to $27 \%$ of the allowed $800 \mathrm{cfm} 50$. If the house in this example had an ACH50 of 2 because the ceiling or the gaps around windows and doors were better sealed, then $Q_{\text {unsealed }}$ could be responsible for about $40 \%$ of the total leakage rate. This number increases to $80 \%$ if the house has an ACH50 of 1. Figure 13 summarizes these results and clearly illustrates how the contribution from airflows through areas that are not easily tackled by air barrier materials can become relevant to the total leakage of tightly-built homes.
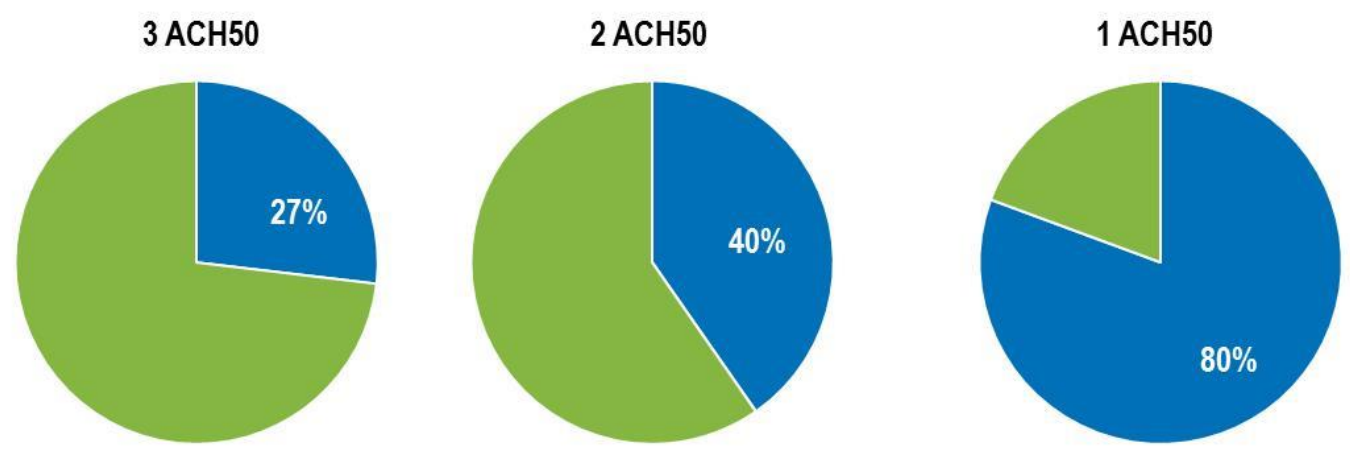

Assessed leakage sites left unsealed

Window, doors, etc.

Figure 13. Potential contribution of the air leakage sites that were assessed in this study to the total air changes per hour in a house. 
As a supplement to the present evaluation, Pallin et al. (2015) used the collected airflow measurements in a stochastic risk assessment to determine their effect on the moisture durability of wall assemblies. This risk study is unique given that it incorporates the variability of flow measurements due to workmanship.

Liquid flashings are probably the simplest available products that can be used to seal the wall-tofoundation and wall-to-roof joints because they can mold around the odd material layouts that are commonly found at these interfaces (Figures 8, 10,12). Figures 14 and 15 show other techniques to seal these joints using tape and/or sill foam gaskets (Hun et al. 2014). Similar techniques can be used to reduce airflow at the wall-to-ceiling joint, that is, by placing a gasket or sealant between the drywall and the top plate.
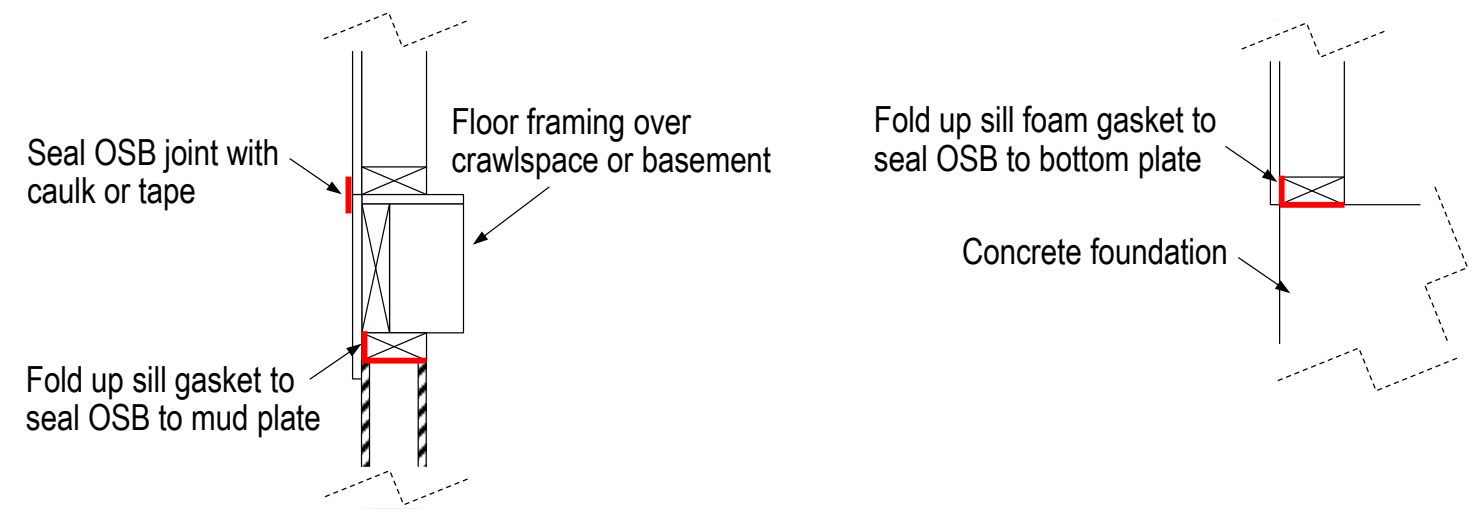

Figure 14. Techniques to seal wall-to-foundation joints (Hun et al. 2014).
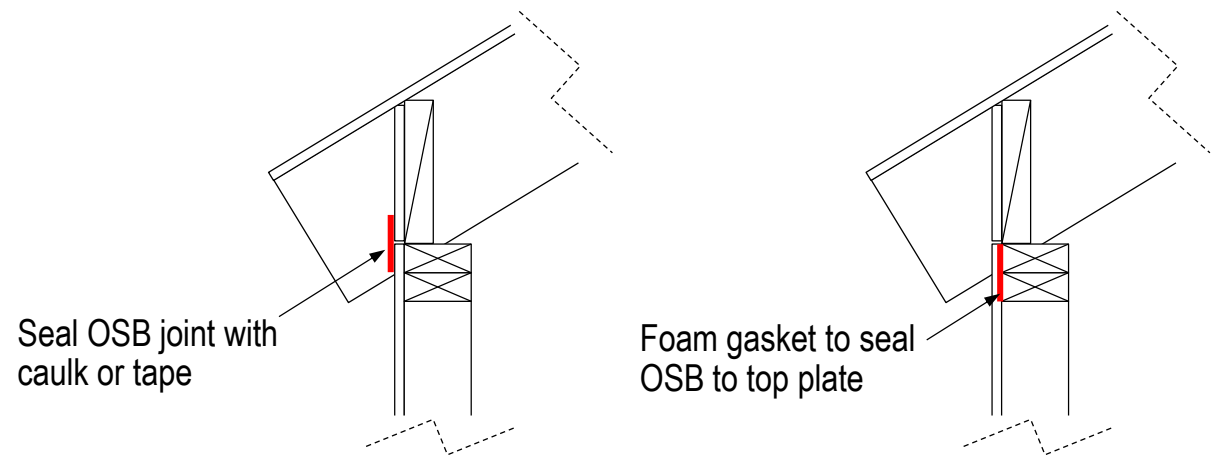

Figure 15. Techniques to seal wall-to-roof joints (Hun et al. 2014). 
Table 1. Air leakage rates from test walls with mechanically-fastened membrane as the air barrier.

\begin{tabular}{|c|c|c|c|c|c|c|c|c|c|c|}
\hline \multirow{2}{*}{ Leakage Site } & \multicolumn{9}{|c|}{ Test Wall } & \multirow{2}{*}{ Avg } \\
\hline & 1 & 2 & 3 & 4 & 5 & 6 & 7 & 8 & 9 & \\
\hline \multicolumn{11}{|l|}{ Infiltration } \\
\hline Wall-to-roof joint $\left(Q_{w r}, \mathrm{cfm} 50 / \mathrm{ft}^{2}\right)$ & 0.02 & 0.09 & 0.04 & 0.02 & 0.03 & 0.03 & 0.04 & 0.05 & 0.05 & 0.04 \\
\hline Wall-to-ceiling joint $\left(Q_{w c}, \mathrm{cfm} 50 / \mathrm{ft}^{2}\right)$ & 0.03 & 0.05 & 0.17 & 0.02 & 0.03 & 0.03 & 0.09 & 0.02 & 0.06 & 0.06 \\
\hline Wall-to-foundation joint $\left(Q_{w f}, \mathrm{cfm} 50 / \mathrm{ft}^{2}\right)$ & 0.08 & 0.12 & 0.03 & 0.04 & 0.05 & 0.04 & 0.01 & 0.04 & 0.04 & 0.05 \\
\hline Electrical outlet w/ cover $\left(Q_{e o}, \mathrm{cfm} 50 / \mathrm{ft}^{2}\right)$ & 0.09 & 0.10 & 0.10 & 0.07 & 0.06 & 0.08 & 0.08 & 0.07 & 0.05 & 0.08 \\
\hline Total $\left(Q_{\text {unsealed }}, \mathrm{cfm} 50 / \mathrm{ft}^{2}\right)$ & 0.10 & 0.16 & 0.18 & 0.12 & 0.13 & 0.12 & 0.12 & 0.14 & 0.13 & 0.13 \\
\hline Total $\left(Q_{\text {unsealed }}, \mathrm{cfm} 75 / \mathrm{ft}^{2}\right)$ & 0.32 & 0.39 & 0.4 & 0.24 & 0.23 & 0.22 & 0.23 & 0.22 & 0.25 & 0.28 \\
\hline \multicolumn{11}{|l|}{ Exfiltration } \\
\hline Wall-to-roof joint $\left(Q_{w r}, \mathrm{cfm} 50 / \mathrm{ft}^{2}\right)$ & 0.01 & 0.12 & 0.05 & 0.03 & 0.05 & 0.03 & 0.02 & 0.05 & 0.04 & 0.04 \\
\hline Wall-to-ceiling joint $\left(Q_{w c}, \mathrm{cfm} 50 / \mathrm{ft}^{2}\right)$ & 0.02 & 0.05 & 0.17 & 0.01 & 0.04 & 0.04 & 0.03 & 0.03 & 0.06 & 0.05 \\
\hline Wall-to-foundation joint $\left(Q_{w f}, \mathrm{cfm} 50 / \mathrm{ft}^{2}\right)$ & 0.08 & 0.15 & 0.05 & 0.06 & 0.09 & 0.07 & 0.02 & 0.06 & 0.09 & 0.07 \\
\hline Electrical outlet w/ cover $\left(Q_{e o}, \mathrm{cfm} 50 / \mathrm{ft}^{2}\right)$ & 0.10 & 0.09 & 0.09 & 0.08 & 0.06 & 0.08 & 0.06 & 0.06 & 0.07 & 0.08 \\
\hline Total $\left(Q_{\text {unsealed }}, \mathrm{cfm} 50 / \mathrm{ft}^{2}\right)$ & 0.08 & 0.20 & 0.18 & 0.11 & 0.12 & 0.13 & 0.10 & 0.14 & 0.11 & 0.13 \\
\hline Total $\left(Q_{\text {unsealed }}, \mathrm{cfm} 75 / \mathrm{ft}^{2}\right)$ & 0.36 & 0.44 & 0.4 & 0.26 & 0.24 & 0.22 & 0.26 & 0.26 & 0.23 & 0.30 \\
\hline
\end{tabular}

Measurements obtained from 2' $\times 8^{\prime}$ test walls. 
Table 2. Air leakage rates from test walls with non-insulating sheathing as the air barrier.

\begin{tabular}{|c|c|c|c|c|c|c|c|c|c|c|}
\hline \multirow{2}{*}{ Leakage Site } & \multicolumn{9}{|c|}{ Test Wall } & \multirow{2}{*}{ Avg } \\
\hline & 1 & 2 & 3 & 4 & 5 & 6 & 7 & 8 & 9 & \\
\hline \multicolumn{11}{|l|}{ Infiltration } \\
\hline Wall-to-roof joint $\left(Q_{w r}, \mathrm{cfm} 50 / \mathrm{ft}^{2}\right)$ & 0.05 & 0.05 & 0.04 & 0.02 & 0.02 & 0.02 & 0.03 & 0.03 & 0.01 & 0.03 \\
\hline Wall-to-ceiling joint $\left(Q_{w c}, \mathrm{cfm} 50 / \mathrm{ft}^{2}\right)$ & 0.07 & 0.02 & 0.06 & 0.04 & 0.02 & 0.05 & 0.06 & 0.07 & 0.07 & 0.05 \\
\hline Wall-to-foundation joint $\left(Q_{w f}, \mathrm{cfm} 50 / \mathrm{ft}^{2}\right)$ & 0.04 & 0.05 & 0.08 & 0.00 & 0.05 & 0.04 & 0.02 & 0.07 & 0.13 & 0.05 \\
\hline Electrical outlet w/ cover $\left(Q_{e o}, \mathrm{cfm} 50 / \mathrm{ft}^{2}\right)$ & 0.08 & 0.08 & 0.07 & 0.11 & 0.09 & 0.08 & 0.08 & 0.13 & 0.09 & 0.09 \\
\hline Total $\left(Q_{\text {unsealed }}, \mathrm{cfm} 50 / \mathrm{ft}^{2}\right)$ & 0.15 & 0.15 & 0.14 & 0.10 & 0.12 & 0.11 & 0.13 & 0.21 & 0.19 & 0.15 \\
\hline Total $\left(Q_{\text {unsealed }}, \mathrm{cfm} 75 / \mathrm{ft}^{2}\right)$ & 0.32 & 0.39 & 0.4 & 0.24 & 0.23 & 0.22 & 0.23 & 0.22 & 0.25 & 0.28 \\
\hline \multicolumn{11}{|l|}{ Exfiltration } \\
\hline Wall-to-roof joint $\left(Q_{w r}, \mathrm{cfm} 50 / \mathrm{ft}^{2}\right)$ & 0.06 & 0.05 & 0.05 & 0.02 & 0.01 & 0.03 & 0.03 & 0.05 & 0.03 & 0.04 \\
\hline Wall-to-ceiling joint $\left(Q_{w c}, \mathrm{cfm} 50 / \mathrm{ft}^{2}\right)$ & 0.07 & 0.02 & 0.05 & 0.03 & 0.02 & 0.06 & 0.05 & 0.08 & 0.09 & 0.05 \\
\hline Wall-to-foundation joint $\left(Q_{w f}, \mathrm{cfm} 50 / \mathrm{ft}^{2}\right)$ & 0.05 & 0.05 & 0.08 & 0.00 & 0.06 & 0.04 & 0.02 & 0.08 & 0.13 & 0.06 \\
\hline Electrical outlet w/ cover $\left(Q_{e o}, \mathrm{cfm} 50 / \mathrm{ft}^{2}\right)$ & 0.08 & 0.07 & 0.07 & 0.11 & 0.11 & 0.09 & 0.08 & 0.13 & 0.08 & 0.09 \\
\hline Total $\left(Q_{\text {unsealed }}, \mathrm{cfm} 50 / \mathrm{ft}^{2}\right)$ & 0.17 & 0.14 & 0.14 & 0.12 & 0.12 & 0.12 & 0.13 & 0.24 & 0.20 & 0.15 \\
\hline Total $\left(Q_{\text {unsealed }}, \mathrm{cfm} 75 / \mathrm{ft}^{2}\right)$ & 0.36 & 0.44 & 0.4 & 0.26 & 0.24 & 0.22 & 0.26 & 0.26 & 0.23 & 0.30 \\
\hline
\end{tabular}

Measurements obtained from 2 ' $\times 8^{\prime}$ test walls. 
Table 3. Air leakage rates from test walls with insulating sheathing as the air barrier.

\begin{tabular}{|c|c|c|c|c|c|c|c|c|c|c|}
\hline \multirow{2}{*}{ Leakage Site } & \multicolumn{9}{|c|}{ Test Wall } & \multirow{2}{*}{ Avg } \\
\hline & 1 & 2 & 3 & 4 & 5 & 6 & 7 & 8 & 9 & \\
\hline \multicolumn{11}{|l|}{ Infiltration } \\
\hline Wall-to-roof joint $\left(Q_{w r}, \mathrm{cfm} 50 / \mathrm{ft}^{2}\right)$ & 0.12 & 0.09 & 0.11 & 0.05 & 0.11 & 0.08 & 0.08 & 0.16 & 0.09 & 0.10 \\
\hline Wall-to-ceiling joint $\left(Q_{w c}, \mathrm{cfm} 50 / \mathrm{ft}^{2}\right)$ & 0.03 & 0.05 & 0.07 & 0.08 & 0.09 & 0.17 & 0.05 & 0.11 & 0.11 & 0.09 \\
\hline Wall-to-foundation joint $\left(Q_{w f}, \mathrm{cfm} 50 / \mathrm{ft}^{2}\right)$ & 0.09 & 0.04 & 0.08 & 0.13 & 0.08 & 0.14 & 0.10 & 0.10 & 0.10 & 0.10 \\
\hline Electrical outlet w/ cover $\left(Q_{e o}, \mathrm{cfm} 50 / \mathrm{ft}^{2}\right)$ & NA & NA & NA & NA & NA & NA & 0.06 & 0.09 & 0.12 & 0.09 \\
\hline Total $\left(Q_{\text {unsealed }}, \mathrm{cfm} 50 / \mathrm{ft}^{2}\right)$ & 0.18 & 0.11 & 0.19 & 0.15 & 0.16 & 0.23 & 0.15 & 0.21 & 0.20 & 0.18 \\
\hline Total $\left(Q_{\text {unsealed }}, \mathrm{cfm} 75 / \mathrm{ft}^{2}\right)$ & 0.32 & 0.39 & 0.4 & 0.24 & 0.23 & 0.22 & 0.23 & 0.22 & 0.25 & 0.28 \\
\hline \multicolumn{11}{|l|}{ Exfiltration } \\
\hline Wall-to-roof joint $\left(Q_{w r}, \mathrm{cfm} 50 / \mathrm{ft}^{2}\right)$ & 0.12 & 0.10 & 0.10 & 0.06 & 0.10 & 0.07 & 0.07 & 0.15 & 0.07 & 0.10 \\
\hline Wall-to-ceiling joint $\left(Q_{w c}, \mathrm{cfm} 50 / \mathrm{ft}^{2}\right)$ & 0.03 & 0.05 & 0.05 & 0.07 & 0.09 & 0.15 & 0.04 & 0.11 & 0.08 & 0.08 \\
\hline Wall-to-foundation joint $\left(Q_{w f}, \mathrm{cfm} 50 / \mathrm{ft}^{2}\right)$ & 0.10 & 0.06 & 0.11 & 0.12 & 0.07 & 0.14 & 0.09 & 0.10 & 0.10 & 0.10 \\
\hline Electrical outlet w/ cover $\left(Q_{e o}, \mathrm{cfm} 50 / \mathrm{ft}^{2}\right)$ & NA & NA & NA & NA & NA & NA & 0.06 & 0.08 & 0.07 & 0.07 \\
\hline Total $\left(Q_{\text {unsealed }}, \mathrm{cfm} 50 / \mathrm{ft}^{2}\right)$ & 0.18 & 0.12 & 0.18 & 0.16 & 0.16 & 0.21 & 0.14 & 0.20 & 0.16 & 0.17 \\
\hline Total $\left(Q_{\text {unsealed }}, \mathrm{cfm} 75 / \mathrm{ft}^{2}\right)$ & 0.36 & 0.44 & 0.4 & 0.26 & 0.24 & 0.22 & 0.26 & 0.26 & 0.23 & 0.30 \\
\hline
\end{tabular}

Measurements obtained from 2 ' $\times 8^{\prime}$ test walls. 


\section{CONCLUSIONS}

This report summarizes the measured airflow rates through typical air leakage sites in homes with air barriers, and how these data vary due to workmanship. The measurements indicate that airflow rates through wall-to-roof joints, wall-to-foundation joints, wall-to-ceiling joints, and covered exterior outlets can be significant contributors to the total air leakage of tightly-built homes. Therefore, builders will have to pay closer attention to these leakage sites to meet code requirements. The report provides a few practical recommendations that builders could follow to seal these areas. Furthermore, the collected data will be useful to designers and researchers that want to take into account the effects of airflow in their hygrothermal analyses. The value of these data is demonstrated by Pallin et al. (2015) who incorporated the variability of these airflow measurements into a stochastic risk assessment that evaluates the moisture durability of wall assemblies. 


\section{REFERENCES}

ASTM International. 2004. ASTM E283. Standard Test Method for Rate of Air Leakage through Exterior Windows, Curtain Walls, and Doors under Specific Pressure Differentials Across the Specimen. Pennsylvania: American Society for Testing and Materials International.

ASTM International. 2011. ASTM E2357. Standard Test Method for Determining Air Leakage of Air Barrier Assemblies. Pennsylvania: American Society for Testing and Materials International.

DOE. 2014. Windows and Building Envelope Research and Development: Roadmap for Emerging Technologies. Washington, DC: US Department of Energy.

Home Innovations Research Labs. Wall System Innovation. 2013. http://energy.gov/sites/prod/files/2013/12/f5/wall_system_innovations_kochkin.pdf

Hun DE, Spafford P, Desjarlais AO. 2014. Evaluation of Air Barriers for Residential Buildings. Oak Ridge National Laboratory. ORNL/TM-2013/604.

IECC. 2012. 2012 International Energy Conservation Code. Country Club Hill, IL: International Code Council.

Lepage R, Schumacher C, Lukachko A. 2013. Moisture management for high r-value walls. Building Science Corporation, Report 1319, prepared for the National Renewable Energy Laboratory.

Maref W, Saber H. 2015. ASHRAE SSPC 160: Risk of condensation and mould growth in wood-frame wall systems. ASHRAE SSPC 160 meetings. 30 June 2015. Atlanta GA.

Pallin S, Boudreaux P, Kehrer M, Hun DE, Jackson RK, Desjarlais AO. In progress, to be published in 2015. Moisture durability assessment of well-insulated wall assemblies. Oak Ridge National Laboratory. 